\title{
Growth Performance and Survival of Clarias gariepinus Larvae Fed with Varying Inclusions of beef Brain Meal
}

\author{
Alain Okoan Achi ${ }^{1,2}$, Rachel Ahou Koumi ${ }^{1}$, Bruno Yapoga Ossey ${ }^{1}$, Wongbé Yté $^{3}$, Issa Nahoua Ouattara ${ }^{2}$, \\ Célestin Boua Atsé ${ }^{1}$ \\ ${ }^{1}$ Département Aquaculture, Centre de Recherches Océanologiques, BPV 18, Abidjan, Côte d'Ivoire. \\ ${ }^{2}$ Laboratoire d'Hydrobiologie, UFR Biosciences, Université Félix Houphouët Boigny, 04 BP 322, Abidjan, Côte d'Ivoire. \\ ${ }^{3}$ Centre National de Recherches Agronomiques, 01 BP 1740 Abidjan 01, Côte d'Ivoire.
}

\section{ARTICLE INFO}

Article history:

Received on: 03/07/2017

Accepted on: 18/08/2017

Available online: 30/10/2017

Key words:

Clarias gariepinus, larvae, feeding, growth, survival, beef brain meal.

\begin{abstract}
Clarias gariepinus culture remains undeveloped in Côte d'Ivoire due to the lack of locally quality feed, fingerlings, and the high cost of imported feed Artemia salina. Because of the importance of feed and feeding strategy in fish fingerling production, beef brain meal was investigated as alternative compounded feed. Feeding trial was completed with five isonitrogenous diets at $35 \%$ crude protein formulated by substituting Artemia salina for beef brain (BB) meal on the basis of crude protein at $0 \%$ (Control diet), $25 \%\left(\mathrm{BB}_{25}\right), 50 \%$ $\left(\mathrm{BB}_{50}\right), 75 \%\left(\mathrm{BB}_{75}\right)$ and $100 \%\left(\mathrm{BB}_{100}\right)$ level. Catfish, Clarias gariepinus larvae with an average weight of $0.006 \pm 0.001 \mathrm{~g}$ were fed with experiment diets in three replicate groups, three times a day (07:00, 12:00 and 17:00 hours) ad libitum 49 days. At the end of rearing period, highest values of growth parameters were recorded from larvae fed with $\mathrm{BB}_{100}, \mathrm{BB}_{75}$, and $\mathrm{BB}_{50}$. Beef brain meal increased the dietary total fat when the feed conversion ratio decreased. Fish fed diets $\mathrm{BB}_{25}$ and $\mathrm{BB}_{50}$ recorded the highest values of survival rate. Studies on the best feeding rates and water quality monitoring should be carried out to improve survival of Clarias gariepinus larvae fed with high level of beef brain meal in diet.
\end{abstract}

\section{INTRODUCTION}

Culture of African catfish, Clarias gariepinus Burchell 1822 has received considerable attention since the early 1970 1980s [1]. This catfish has been considered a fish of great promise for fish farming in Africa because of its high growth rate, resistance, and appreciation in a wide number of African countries. Clarias gariepinus has become a popular species for aquaculture in sub-Saharan Africa particularly in Nigeria where it represents the most aquaculture produced catfish [2]. However, Clarias gariepinus culture remains undeveloped in Côte d'Ivoire $[3,4]$. The production of Clarias gariepinus and catfish generally faces lack of capital, high cost of imported quality feed, lack of locally quality feed, little presence of hatcheries producing high quality seed, predation and cannibalism of larvae, and lack of fingerlings $[5,6,4]$. Therefore, fingerling production is one of the many challenges for successful Clarias gariepinus culture in Côte d'Ivoire. Feeds and feeding of the larvae and fry of the

* Corresponding Author

Rachel Ahou Koumi, Centre de Recherches Océanologiques, BPV 18, Abidjan, Côte d'Ivoire. Phone: (+225) 21355014 / (+225) 07871069; Email: koumirachel @yahoo.fr catfishes influence the growth and survival of the fish [7, 8]. Starter feeds play a key role in the growth of larvae. They provide the required nutriments (35-40\% proteins), amino acids and fatty acids to promote optimal larvae growth and health [9]. Artemia nauplii and decapsulated cysts are used with successful outcomes in feeding most larvae and fry of $C$. gariepinus $[10,11$, $12,13]$.

Artemia salina was used as the main protein source due to its high proteins, balanced amino acids profile, essential fatty acids, minerals and vitamins content, palatability, and highly digestibility [14].

In addition, Artemia cysts can be stored in cans during a longer period and used after $24 \mathrm{~h}$ of incubation, making them the most convenient and available starter feed for Aquaculture [15]. However the increasing cost of Artemia cysts is a major constraint to most fish farmers especially in West Africa. Therefore, it is of main importance to carry out more studies on alternative feeds. Substitution of imported Artemia salina by locally coumpouded diets is essential for lowering production cost while promoting quality catfish fingerlings production. Also various conventional and non-conventional animal by-products have been tested to substitute Artemia salina in catfish compounded starter feed [16, $15,17,18]$. 
In these feeding trials, the diets were formulated with roquette seed meal, rotifer Brachionus calyciflorus, fermented fish silage, probiotic Lactobacillus acidophilus, beef brain, beef brain meal, maggot meal, fish meal, blood meal, and soybean meal [15, 16, 17]. Ossey et al. [19, 20] reported that the use of beef brain meal (36.5\% proteins; $32 \%$ lipid) fortified with iron, chlorine, phosphorus, catfish premix vitamins/amino-acids, lysine and methionine in formulated diet at $35 \%$ proteins content improves beef brain meal potentials in Heterobranchus longifilis larvae feeding. Sheap beef brain is locally available, and the production process of fortified beef brain meal is simple. Ossey et al. [19, 20] have reported good growth and feed utilization results using beef brain meal in Hetebranchus longifilis larvae. However, beef brain meal has not yet been used to substitute Artemia salina in Clarias gariepinus larvae diets. The aim of this study was to determine the optimal level of replacement of Artemia salina by beef brain meal in the diet of Clarias gariepinus larvae. The growth trial responses may help to reduce $C$. gariepinus fingerling production cost and increase fingerlings availability for improving Côte d'Ivoire aquaculture catfish production.

\section{MATERIALS AND METHODS 2.1 Experimental diets}

Artemia salina, beef brain meal, maize flour, Maridav (imported enriched soy bean meal) were used as main raw materials to formulate diets in this study. Palm oil, Lysin, methionin, and VITAMYNOLITE super premix were added to the different mix of raw materials. Artemia salina was bought from a pharmacy shop at Abidjan, Ivory Coast at 210.57 USD kg $^{-1}$ and hatched followed by Slembrouck and Legendre [21] to obtain 1.5 $\mathrm{kg}$ of Artemia salina meal. Beef brain was purchased from local market in Abidjan at $2.32-2.65 \mathrm{USD} \mathrm{kg}^{-1}$, then, 4-5,5 $\mathrm{kg}$ of beef brain were dried at $80^{\circ} \mathrm{C}$ for $24 \mathrm{~h}$ and crushed into powdery to obtained $1 \mathrm{~kg}$ of beef brain meal ( $\left.9.28-14.58 \mathrm{USD} \mathrm{kg} \mathrm{kg}^{-1}\right)$ as described by Ossey et al. [19]. Maize flour, Maridav (imported enriched Soy bean meal), palm oil, vitamins and amino acids were obtained from the local animal feeds sellers. Artemia salina (49.0\% crude proteins), enriched soy bean meal $(44.8 \%$ crude proteins) maize flour $(09.50 \%$ crude proteins), palm oil $(2 \%)$, Lysine $(2.13 \%)$, Methionine $(1.61 \%)$ and VITAMYNOLYTE super premix $(2 \%)$ were used for balanced control diet formulation at $35 \%$ proteins (Table 1 ).

Then, five isonitrogenous diets at $35 \%$ crude proteins were formulated by substituting Artemia salina by beef brain meal ( $36.50 \%$ crude proteins) on the basis of crude proteins as follows: Control diet $=0 \%$ beef brain proteins replaced Artemia salina proteins; $\left(\mathrm{BB}_{25}\right)=25 \%$ beef brain proteins replaced Artemia salina proteins; $\left(\mathrm{BB}_{50}\right)=50 \%$ beef brain proteins replaced Artemia salina proteins; $\left(\mathrm{BB}_{75}\right)=75 \%$ beef brain proteins replaced Artemia salina proteins and $\left(\mathrm{BB}_{100}\right)=100 \%$ beef brain proteins replaced Artemia salina proteins. All diets were formulated using linear programming method as described by Koumi [22]. Ingredients and chemical composition of the control and experiment diets are presented in Table1.

For each formula, all the ingredients were weighted and ground using a homogenous mixture grinder. Warm water at $80^{\circ} \mathrm{C}$ $\left(800 \mathrm{Ml} \mathrm{kg}^{-1}\right)$ was added and mixed. The paste obtained was dried in electric oven at $60^{\circ} \mathrm{C}$ for 48 hours. The dried paste was crushed into powdery with pestle and mortar to obtained meal, then was hydrated by vapor with a combined mechanism saucepan / sieve (diameter $=200 \mu \mathrm{m}$ ) as described by Ossey et al. [19]. All diets were stored in a plastic container at $-20^{\circ} \mathrm{C}$ until use.

Table 1: Formulation (\%) and proximate composition of the diets.

\begin{tabular}{|c|c|c|c|c|c|}
\hline \multirow[b]{2}{*}{ Ingredients composition (\%) } & \multicolumn{5}{|c|}{ Beef brain meal inclusion } \\
\hline & Control diet $(0 \%)$ & $\mathbf{B B}_{25}(25 \%)$ & $\mathrm{BB}_{50}(50 \%)$ & $\mathbf{B B}_{75}(75 \%)$ & $\mathrm{BB}_{100}(100 \%)$ \\
\hline Artemia meal & 57.80 & 44.20 & 30.00 & 15.21 & 0.00 \\
\hline Beef brain meal & 0.00 & 20.06 & 41.50 & 61.60 & 84.50 \\
\hline Maridav $^{1}$ & 10.00 & 10.00 & 10.00 & 10.00 & 10.00 \\
\hline Maize flour & 24.56 & 18.00 & 10.76 & 5.57 & 1.77 \\
\hline Palm oil & 2.00 & 2.00 & 2.00 & 2.00 & 2.00 \\
\hline Lysine & 2.13 & 2.13 & 2.13 & 2.13 & 2.13 \\
\hline Methionine & 1.61 & 1.61 & 1.61 & 1.61 & 1.61 \\
\hline VITAMYNOLYTE Super prémix ${ }^{2}$ & 2.00 & 2.00 & 2.00 & 2.00 & 2.00 \\
\hline Total $(g)$ & 100 & 100 & 100 & 100 & 100 \\
\hline \multicolumn{6}{|l|}{ Proximate analysis } \\
\hline Moisture (\%) & 10.60 & 10.88 & 11.08 & 11.18 & 08.00 \\
\hline Crude proteins (\% DM) & 35.13 & 35.16 & 35.34 & 34.97 & 35.41 \\
\hline Total fat $(\% \mathrm{DM})$ & 04.76 & 14.54 & 24.99 & 34.84 & 46.10 \\
\hline Ash (\% DM) & 03.21 & 03.12 & 03.03 & 02.93 & 02.89 \\
\hline Crude fiber (\% DM) & 03.90 & 03.03 & 02.11 & 01.22 & 0.33 \\
\hline Nitrogen free extract (NFE) $(\% \mathrm{DM})^{3}$ & 42.40 & 33.27 & 23.45 & 14.86 & 07.27 \\
\hline Gross energy $\left(\mathrm{kj} \mathrm{g}^{-1}\right)^{4}$ & 16.94 & 19.18 & 21.60 & 23.87 & 27.04 \\
\hline $\mathrm{P} / \mathrm{E}\left(\mathrm{mg} \mathrm{kj}^{1}\right)^{5}$ & 20.73 & 18.33 & 16.36 & 14.65 & 13.09 \\
\hline
\end{tabular}

${ }^{1}$ Composition for $1 \mathrm{~kg}$ of Maridav; Crude Protein = 44, 8\%; Fat = 3, 5\%; Ash =12, 1\%; Moisture = 9, 5\%; Crude fiber = 02, 9\%; Lysine = 03, 2\%; Methionine = 01, 2\%; Methionine + Cysteine $=01,8 \% ;$ Calcium $=02,2 \% ;$ Phosphorus biodisp $=01,0 \%$; Sodium $=0,5 \%$; Vitamins A = 46,000 IUI; Vitamins D3=09, 590 IUI; Vitamins E $=63$ $\mathrm{mg}$; Vitamins K3 = $6 \mathrm{mg}$; Vitamins B1 = $4 \mathrm{mg}$; Vitamins B2 = 20,00 mg; Niacin=115,00 mg; Pantothenic acid=35,00 mg; Vitamins B6= 08,00 mg ; Vitamins B12 = 97,00 $\mathrm{mg}$; Biotin =194,00 mg; Folic acid = 2,00 mg; Choline chloride = 807,00 mg; Iron = 496,00 mg; Copper = 401,00 mg; Zinc = 232,00 mg; Manganese = 341,00 mg; Iodine $=04,00 \mathrm{mg}$; Selenium $=0,60 \mathrm{mg}$; Salinomycin $=226,00 \mathrm{ppm}^{2}$ Composition for $1 \mathbf{~ k g}$ of premix; Vitamins A=12,00 M UI; Vitamins D3 = 03,20 M UI ; Vitamins $\mathrm{E}=2500 \mathrm{mg}$; Vitamins K3=4000 mg; Vitamins B1=5000 mg; Vitamins B2=500 mg; Vitamins B6 =2500 mg Vitamins B12 = 5 mg; Vitamins C = $10000 \mathrm{mg}$; Nicotinic acid $=2000 \mathrm{mg} ;$ Calcium panthotenate $=6000 \mathrm{mg} ;$ Biotin $=5 \mathrm{mg} ;$ Folic acid $=250 \mathrm{mg}$; Iron-Copper-Zinc-Manganese-Cobalt- Magnesium-Iodine $=90000 \mathrm{mg}$; Potassium chloride $=15000 \mathrm{mg} ;$ Amino acid $=25000 \mathrm{mg} ;{ }^{3}$ Nitrogen free extract $(\mathbf{N F E})=100-(\%$ protein $+\%$ lipid $+\%$ moisture $+\%$ ash $+\%$ fiber $) ;{ }^{4}$ Gross Energy $=$ protein $\times 22,20 \mathrm{~kJ} / \mathrm{g}+$ lipid $\times 38,90 \mathrm{~kJ} / \mathrm{g}+$ Nitrogen free extract $\times 17,20 \mathrm{~kJ} / \mathrm{g} ;{ }^{5} \mathbf{P} / \mathbf{E}=$ Protein to energy ratio in $\mathrm{mg}$ protein $/ \mathrm{Kj}$ gross energy. 


\subsection{Experimental fish and feeding trial}

Total of 750 catfish Clarias gariepinus larvae with average weight $0.006 \pm 0.001 \mathrm{~g}$ were used. The larvae used in this experiment were obtained from of artificial reproduction following Legendre [23] at Centre de Recherches Oceanologiques (CRO), Côte d'Ivoire. Three days-age larvae were transferred in aquarium $(39.4 \mathrm{~cm} \times 50.2 \mathrm{~cm} \times 27 \mathrm{~cm})$, capacity of $50 \mathrm{~L}$ and acclimated in four days prior to the beginning of the growth trial. Three replicate were constituted by diet and the feeding trial was conducted in 15 aquariums in CRO hatchery. Fish were weighted counted and stored at density of 1 larva $\mathrm{L}^{-1}$ in each aquarium. All the larvae were fed experimental diets three times daily (07:00, 12:00 and 17:00 hours) ad libitum during 49 days. Every day, dead fish of each aquarium were removed and counted. Once a week, fifteen larvae were randomly sampled in each aquarium to measure total weight using electronic balance SARTORIUS L $6200 \mathrm{~S}$ (accuracy of $0.001 \mathrm{~g}$ ) and the total length (L) was measured to the nearest half millimeter.

Subsequently, all larvae were weight and ration was adjusted to reflect the new weight. At the end of rearing, all survival fish were collected, weighted, and counted from each aquarium and individual total length and body wet weight were also recorded by fish. A distinction was draw between cannibalism and natural death. Missing fish were presumed to have succumbed to a complete cannibalism [24]. Natural death was determined by the presence of complete fish floating in the aquarium [25].

\subsection{Growth parameters and nutrient utilization}

The growth indices and nutrient utilization parameters were calculated for each treatment as follows: Weight gain (WG) ( $g)$ = final body weight - initial body weight; Daily weight gain (DWG) $\left(\mathrm{g}\right.$ day $\left.^{-1}\right)=$ (final body weight - initial body weight $) /\left(\right.$ number of day); Specific growth rate $(\mathrm{SGR})\left(\% \mathrm{day}^{-1}\right)=$ [ln (final body weight) $-\ln$ (initial body weight) $] \times 100 /$ number of day; Feed conversion ratio $(\mathrm{FCR})=$ total weight of feed consumed $(\mathrm{g}) /$ wet biomass gain ( $\mathrm{g}$ ); Total weight of feed consumed is obtained by total feed distributed fewer uneaten food; Survival rate (SR) $(\%)=($ final number of larvae/initial number of larvae $) \times 100$; Cannibalism rate $(\mathrm{CR})(\%)=$ (number of larvae missing + incomplete dead larvae/initial number of larvae) $\times 100$; Mortality rate $(\mathrm{MR})(\%)=$ (number of complete dead larvae/initial number of larvae) $\times 100$.

\subsection{Biochemical analysis}

The proximate composition of experimental diets was determined according to AOAC [26] methods. Dry matter (DM) was determined after oven drying at $105^{\circ} \mathrm{C}$ for 24 hours until constant weight; crude protein (\% $\mathrm{N}$ x 6.25) was determined using kjeldahl method; crude lipid by Soxhlet extraction with hexane; Ash was measured by incineration at $550^{\circ} \mathrm{C}$ in a muffle furnace for 24 hours; crude fibre were measured by acid digestion following by ashing the dry residue at $550^{\circ} \mathrm{C}$ in a muffle furnace for $4 \mathrm{~h}$, while nitrogen-free extract (NFE) was calculated by difference.
The gross energy contents of the diets were calculated on the basis of their crude proteins, lipid and carbohydrate contents using the energy equivalents of $22.2,38.9$ and $17.15 \mathrm{~kJ} \mathrm{~g}^{-1}$ respectively [27].

\subsection{Statistical Analysis}

Data analysis was performed using Statistica 7.1 software. Data were presented as mean \pm standard deviation (SD). Results were compared using one-way analysis of variance (ANOVA). The Tukey's multiple range tests was used to compare differences among treatment means. Significant differences were considered at $\mathrm{p}<0.05$.

\section{RESULTS}

The growth performance parameters, nutrient utilization indices and survival rate of Clarias gariepinus fed Control diet and experimental diets $\mathrm{BB}_{25}, \mathrm{BB}_{50}, \mathrm{BB}_{75}$ and $\mathrm{BB}_{100}$ are shown in (Table 2).

\subsection{Growth performance parameters}

Final body weight (FBW), weight gain (WG), daily weight gain (DWG) and specific growth rate (SGR) were significantly $(p<0.05)$ affected by the levels of Artemia protein substitution by beef brain protein in control diet. The highest significant values of final body weight and weight gain were recorded from larvae fed $\mathrm{BB}_{100}(\mathrm{FBW}=3.45 \pm 0.02 \mathrm{~g} ; \mathrm{WG}=3.44$ $\pm 0.01 \mathrm{~g})$ followed by fish fed $\mathrm{BB}_{75}(\mathrm{FBW}=3.28 \pm 0.03 \mathrm{~g} ; \mathrm{WG}=$ $3.27 \pm 0.02 \mathrm{~g})$ and $\mathrm{BB}_{50}(\mathrm{FBW}=3.17 \pm 0.02 \mathrm{~g} ; \mathrm{WG}=3.16 \pm 0.03$ g) which were different significantly.

The lowest significant $(\mathrm{p}<0.05)$ values of these parameters were obtained in larvae fed $\mathrm{BB}_{25}(\mathrm{FBW}=2.83 \pm 0.10$ $\mathrm{g} ; \mathrm{WG}=2.82 \pm 0.10 \mathrm{~g})$ and control diet $(2.19 \pm 0.13 \mathrm{~g} ; 2.18 \pm 0.16$ g). However, significant $(\mathrm{p}<0.05)$ highest values of daily weight gain and specific growth rate were recorded by fish fed $\mathrm{BB}_{100}(0.07$ $\pm 0.005 \mathrm{~g} \mathrm{day}^{-1} ; 12.83 \pm 0.13 \%$ day $\left.^{-1}\right), \mathrm{BB}_{75}\left(0.07 \pm 0.004 \mathrm{~g} \mathrm{day}^{-1}\right.$; $12.67 \pm 0.15 \%$ day $\left.^{-1}\right)$ and $\mathrm{BB}_{50}\left(0.06 \pm 0.005 \mathrm{~g} \mathrm{day}^{-1} ; 12.54 \pm 0.14\right.$ $\%$ day $\left.^{-1}\right)$ which did not differ significantly $(\mathrm{p}<0.05)$. The significantly lowest values of these two parameters were observed in fish fed control diet.

\subsection{Nutrient utilization indices}

The different values of feed conversion ratio (FCR) recorded in growth trial were affected by the level of Artemia salina replacement by beef brain meal in control diet. Results showed that FCR values tended to decreased with beef brain meal inclusion level in control diet.

The significant $(\mathrm{p}<0.05)$ best value of feed conversion ratio was recorded from fish fed $\mathrm{BB}_{100}(1.22 \pm 0.04), \mathrm{BB}_{75}(1.33 \pm$ $0.24)$ and $\mathrm{BB}_{50}(1.43 \pm 0.27)$ without significant difference followed by those of fish fed $\mathrm{BB}_{25}(1.68 \pm 0.12)$ and the lowest value of this parameter was obtained by fish fed control diet (1.88 \pm 0.29 ). 
Table 2: Growth performance, nutrient utilization and survival rate of Clarias gariepinus larvae fed with the experimental diets.

\begin{tabular}{|c|c|c|c|c|c|}
\hline \multirow{2}{*}{ Parameters } & \multicolumn{5}{|c|}{ Experimental diets } \\
\hline & Control diet (0\%) & $\mathrm{BB}_{25}(25 \%)$ & $\mathrm{BB}_{50}(50 \%)$ & $\mathrm{BB}_{75}(75 \%)$ & $\mathrm{BB}_{100}(100 \%)$ \\
\hline Initial body weight (g) & $0.006 \pm 0.001$ & $0.006 \pm 0.001$ & $0.006 \pm 0.001$ & $0.006 \pm 0.001$ & $0.006 \pm 0.001$ \\
\hline Final body weight (g) & $2.19 \pm 0.13^{\mathrm{a}}$ & $2.83 \pm 0.10^{\mathrm{b}}$ & $3.17 \pm 0.02^{\mathrm{c}}$ & $3.28 \pm 0.03^{\mathrm{d}}$ & $3.45 \pm 0.02^{\mathrm{e}}$ \\
\hline Weight gain $(\mathrm{g})$ & $2.18 \pm 0.16^{\mathrm{a}}$ & $2.82 \pm 0.10^{\mathrm{b}}$ & $3.16 \pm 0.03^{\mathrm{c}}$ & $3.27 \pm 0.02^{\mathrm{d}}$ & $3.44 \pm 0.01^{\mathrm{e}}$ \\
\hline Daily weight gain $\left(\mathrm{g} \mathrm{day}^{-1}\right)$ & $0.04 \pm 0.01^{\mathrm{a}}$ & $0.06 \pm 0.010^{\mathrm{b}}$ & $0.06 \pm 0.005^{\mathrm{bc}}$ & $0.07 \pm 0.004^{\mathrm{c}}$ & $0.07 \pm 0.005^{\mathrm{c}}$ \\
\hline Specific growth rate $\left(\%\right.$ day $\left.^{-1}\right)$ & $11.85 \pm 0.05^{\mathrm{a}}$ & $12.37 \pm 0.23^{\mathrm{b}}$ & $12.54 \pm 0.14^{\mathrm{bc}}$ & $12.67 \pm 0.15^{\mathrm{bc}}$ & $12.83 \pm 0.13^{\mathrm{c}}$ \\
\hline Initial biomass of fish $(\mathrm{g})$ & $0.30 \pm 0.001^{\mathrm{a}}$ & $0.30 \pm 0.001^{\mathrm{a}}$ & $0.30 \pm 0.001^{\mathrm{a}}$ & $0.30 \pm 0.001^{\mathrm{a}}$ & $0.30 \pm 0.001^{\mathrm{a}}$ \\
\hline Final biomass of fish $(\mathrm{g})$ & $82.53 \pm 0.10^{\mathrm{a}}$ & $109.67 \pm 0.21^{\mathrm{b}}$ & $114.16 \pm 0.10^{\mathrm{d}}$ & $112.04 \pm 0.02^{\mathrm{c}}$ & $120.82 \pm 0.23^{\mathrm{e}}$ \\
\hline Biomass gain $(\mathrm{g})$ & $82.23 \pm 0.11^{\mathrm{a}}$ & $109.37 \pm 0.20^{b}$ & $113.86 \pm 0.24^{\mathrm{d}}$ & $111.74 \pm 0.31^{\mathrm{c}}$ & $120.52 \pm 0.13^{\mathrm{e}}$ \\
\hline Quantity of feed used (g) & $155.16 \pm 0.11^{\mathrm{c}}$ & $184.24 \pm 0.12^{\mathrm{e}}$ & $163.24 \pm 0.14^{\mathrm{d}}$ & $149.01 \pm 0.03^{\mathrm{b}}$ & $147.50 \pm 0.21^{\mathrm{a}}$ \\
\hline Feed conversion ratio & $1.88 \pm 0.29^{\mathrm{b}}$ & $1.68 \pm 0.12^{\mathrm{b}}$ & $1.43 \pm 0.27^{\mathrm{ab}}$ & $1.33 \pm 0.24^{\mathrm{a}}$ & $1.22 \pm 0.04^{\mathrm{a}}$ \\
\hline Cannibalism rate $(\%)$ & $23.32 \pm 4.28^{\mathrm{bc}}$ & $19.90 \pm 0.97^{\mathrm{a}}$ & $21.85 \pm 0.48^{b}$ & $26.90 \pm 0.29^{c}$ & $29.66 \pm 0.25^{\mathrm{d}}$ \\
\hline Mortality rate $(\%)$ & $2.21 \pm 0.0^{\mathrm{b}}$ & $1.35 \pm 0.11^{\mathrm{a}}$ & $1.40 \pm 0.20^{\mathrm{a}}$ & $1.75 \pm 0.31^{\mathrm{ab}}$ & $3.34 \pm 0.03^{c}$ \\
\hline Survival rate $(\%)$ & $74.47 \pm 0.46^{\mathrm{b}}$ & $78.75 \pm 1.14^{\mathrm{c}}$ & $76.75 \pm 0.25^{\mathrm{c}}$ & $71.35 \pm 0.32^{\mathrm{b}}$ & $67.00 \pm 0.35^{\mathrm{a}}$ \\
\hline
\end{tabular}

Mean values \pm SD in the same row sharing the different superscript are significantly different $(\mathrm{p}<0.05)$.

\subsection{Survival, cannibalism and mortality}

Survival, cannibalism and mortality rate values showed significant influence of the level of beef brain inclusion in control diet (Table 2). Cannibalism rate means values ranged between 19.90-29.66 \%; mortality rate recorded in the growth trial were low and ranged between $1.35-3.34 \%$ while survival rate ranged between $67.00-78.75 \%$. The highest $(\mathrm{p}<0.05)$ values of cannibalism and mortality rate with consequently the lowest values of survival rate were recorded by fish fed diet $\mathrm{BB}_{100}$ followed by fish fed diet $\mathrm{BB}_{75}$ and control diet. When, significant highest values of survival rate with the lowest rate of cannibalism and mortality were recorded from fish fed diets $\mathrm{BB}_{25}$ and $\mathrm{BB}_{50}$ without significant difference between survival and mortality rate.

\section{DISCUSSION}

The final body weight (2.19-3.45 g) recorded in this study suggests that all the tested diets were suitable for rearing catfish Clarias gariepinus larvae. The Artemia meal substitution levels for beef brain meal did not negatively affect palatability of the diet. Moreover, the replacement of 50, 75, and $100 \%$ of Artemia proteins by beef brain proteins in diets provided the highest values of growth parameters. These results corroborated with Ossey et al. $[19,20]$ who showed that beef brain meal in larvae catfish $H$. longifilis diet enhances palpability, acceptability and growth. The best growth observed with these diets formulated with beef brain meal could be due to the nutritional quality of these diets associated with their good digestibility by Clarias gariepinus larvae. In fact, diets $\mathrm{BB}_{25}, \mathrm{BB}_{50}, \mathrm{BB}_{75}, \mathrm{BB}_{100}$, and control diets contain similar crude proteins. However, diets $\mathrm{BB}_{50}$, $\mathrm{BB}_{75}$ and $\mathrm{BB}_{100}$ presented the highest values of dietary total fat $(24.99-46.10 \%)$ and gross energy $\left(21.60-27.04 \mathrm{kj} \mathrm{g}^{-1}\right)$ with the lowest values of the $\mathrm{P} / \mathrm{E}$ ratio (13.09-16.36 $\mathrm{mg} \mathrm{kj}^{-1}$ ). In the present study, the high level of dietary lipid which increases feed gross energy and the $\mathrm{P} / \mathrm{E}$ ratio appeared to be an important factor influencing Clarias gariepinus larvae growth and feed utilization. This observation is in agreement with Ossey et al. [19, 20,17] who observed an increasing growth of catfish Heterobranchus longifilis larvae with increasing dietary lipid level in diets containing 35\% crude protein. Lipids are a group of natural organic compounds comprising fats, oils, phospholipids and sterols. Moreover fats have distinct advantage of being almost completely digestible. In fish ration, the neutral lipid components and the sources of lipids are useful elements for diet formulation and are especially essential in feed of fry and fingerlings, which require high energy intake for rapid growth $[28,29]$. They are nonprotein calorie sources which are generally more digestible than some carbohydrates [30]. Dietary lipids influence flavor and texture of prepared feeds. They were utilized in fish as a major energy source to spare proteins, provide essential fatty acids needed for proper functioning of many physiological processes and maintenance of membrane fluidity and permeability as well as for growth and survival of fish [31, 32, 33]. In general, lipid requirement for catfish (Clarias gariepinus, Heterobranchus longifilis) ranges between 5-10\%. However, Cahu [34] showed that the increase of catfish dietary lipid more than lipid requirement improves growth. Moreover, Lee and Sinnhuber [28] reported that catfish can use $20-30 \%$ of the dry diet ingredients as fat, provided that adequate amounts of choline, methionine and tocopheral are present in the ration. In this study, the higher lipid level more than catfish lipid requirement and the high values of gross energy present in the diets formulated at $35 \%$ proteins was an advantage for good growth of larvae. This observation indicates good nutritional quality of the nutriments and biological values of feeds $\mathrm{BB}_{50} ; \mathrm{BB}_{75}$ and $\mathrm{BB}_{100}$. In addition, the SGR values obtained with these diets $\left(12.54-12.83 \%\right.$ day $\left.^{-1}\right)$ were similar to the growth rates (12.03$12.73 \% \mathrm{day}^{-1}$ ) of larval and fry of Clarias gariepinus fed with Artemia salina and commercial high proteins (53.2-54\%) diets [8]. These growth rates suggest that the tested diets $\mathrm{BB}_{50}, \mathrm{BB}_{75}$, and $\mathrm{BB}_{100}$ were suitable for rearing Clarias gariepinus catfish larvae.

The results also showed that relative highest cannibalism and mortality rates resulted in lowest survival rates for larvae fed with diets $\mathrm{BB}_{75}$ and $\mathrm{BB}_{100}$. During the experiment, water turbidity increased in the order diets $\mathrm{BB}_{50}<\mathrm{BB}_{75}<\mathrm{BB}_{100}$ in the aquarium because of the high lipid contents in feeds along with unconsumed feeds particles. Some studies have revealed that 
cannibalism and mortality are influenced by water quality management, fish density, feeding strategies, competition of food and stress [15, 25, 35]. In this study, larvae were stocked at low density ( 1 larva $\left.\mathrm{L}^{-1}\right)$ and fed at libitium three times daily. Feeding fish at satiation could affect water quality and increase fish stress, mortality, and cannibalism. According to Faruque et al. [15], high feeding levels result in the highest mortality rate while low feeding levels might cause lower survival rate and growth. In order to minimize fish stress and offer the better environment for larvae growth, the best feeding rates of larvae that promote survival must be investigated with high lipid content feeds formulated with beef brain meal.

\section{CONCLUSION}

Growth trial responses showed that substitution of Artemia salina proteins for beef brain meal proteins in larvae Clarias gariepinus diets improves growth and feed efficiencies. The success of this substitution promotes locally available low cost quality feed for fingerling production. Studies on the best feeding rates and water quality monitoring should be carried out to improve survival of Clarias gariepinus larvae with beef brain diets. The utilization of high lipid beef brain diets for Clarias gariepinus larvae growth needs the determination of the best feeding rate, frequency and the monitoring of the water quality.

\section{ACKNOWLEDGEMENT}

This work was conducted in the framework of the PAFARCI (Project to Support the Recovery of Agricultural Sectors in Côte d'Ivoire) project funded by the FIRCA, the National Inter-professional Fund for Research and Agricultural Council). The authors also thank all partners from the study for their implication in the experiment and the collection of data.

Financial support and sponsorship: The authors are grateful to FIRCA, for the financing of this research.

Conflict of Interests: There are no conflicts of interest.

\section{REFERENCE}

1. Graaf GJ, Galemoni F, Banzoussi B. The artificial reproduction and fingerling production of the African catfish Clarias gariepinus (Burchell 1822) in protected and unprotected ponds. In: Graaf G, editor. The artificial reproduction and pond rearing of the African catfish Clarias gariepinus, Kisumu, KENYA: FAO/UNDP/BSFKEN/86/027; 1994.p. 1-11.

2. FDF (Federal Department of Fisheries). Fisheries Statistics of Nigeria. 4th Ed. 1995-2007, FDF; 2007.

3. Koumi AR, Kimou BN, Atsé BC, Ouattara IN, Kouamé LP. Fish feeds used in Côte d'Ivoire: Nature, quality, use and productivity. Asian Journal of Agriculture and Food Sciences. 2015; 3 (2): 225236

4. JICA (Agence Japonaise de Coopération Internationale). Projet de relance de la production piscicole continentale en république de Côte d'Ivoire: Rapport de l'étude d'état des lieux. (JICA), OAFIC CO., LTD. INTEM consulting, INC; 2016.
5. Anetekhai MA, Akin-Oriola GA, Aderinola OJ, Akintola SL. Steps ahead for Aquaculture development in Sub-Saharan African- The case of Nigeria. Aquaculture. 2004; 239:237-248.

6. Adewumi AA, Olaleye VF. Catfish culture in Nigeria: Progress, prospects and problems. African Journal of Agricultural Research. 2011; 6 (6): 1281-1285.

7. Enyidi U, Pirhonen J, Vielma J. Effects of substituting soybean (Glycine max) meal with Bambaranut (Voandzeia subterranea) meal on growth performance and survival of African catfish (Clarias gariepinus) larvae. International Journal of Fisheries and Aquatic Studies. 2014; 1 (3):152-157.

8. Yakubu AF, Nwogu NA, Olaji ED, Adams TE. Impact of threedifferent commercial feed on the growth and survival of Clarias gariepinus Burchell, 1822 fry in aquaria glass tanks. American Journal of Experimental Agriculture. 2015; 9 (1): 1-6.

9. Ayinla OA. Nutritive and Reproductive Performance of Clarias gariepinus (Burchell 1822). Ph.D Thesis, University of Ibadan, Nigeria; 1988.

10. Pector RA. Comparative study on the use of different preparations of decapsulated Artemia cysts as food for rearing African catfish (Clarias gariepinus) larvae. Journal of World Aquaculture Society. 1994; 25 (3):320-324.

11. Olurin KB, Iwuchukwu PO, Oladapo O. Larval rearing of African catfish, Clarias gariepinus fed capsulated Artemia, wild copepods or commercial diet. African Journal of food Sciences and Technology. 2012; 3 (8):182-185.

12. Ajepe RG, Hammed AM, Amosu AO, Fashina-Bombata HA. Comparative Study of Artemia (Brine Shrimp) and Ceriodaphnia (Zooplankton) as Foods for Catfish Larvae. American Journal of Experimental Agriculture. 2014; 4 (7): 857-865.

13. Adewumi AA. Growth performance and survival of Clarias gariepinus hatchlings fed different starter diets. European Journal of Experimental Biology. 2015; 5 (3):1-5.

14. Ben Naceur H, Ben Rejeb Jenhani A, Romdhane MS. Valorisation de l'Artemia (crustacea; branchiopoda) de la saline (Sahel tunisien). Bulletin de la Société Zoologie. 2008; 133 : 185-192

15. Faruque MM, Kawser Ahmed MD, Quddus MMA. Use of live food and artificial diet supply for the growth and survival of African catfish (Clarias gariepinus) larvae. World Journal of Zoology. 2010; 5 (2): 82-89.

16. Appelbaum S, McGeer JC. Effect of diet and light regime on growth and survival of African catfish (Clarias gariepinus) larvae and early juveniles. Aquaculture Nutrition. 2002. 4 (3): 157-164.

17. Ossey YB, Koumi AR, Koffi KM, Atsé BC, Kouamé PL. Growth performance, feed efficiency and body composition of larvae $H$. longifilis fed different beef brain meal dietary protein levels. International Journal of Sciences and Research. 2014. 3 (7): 2319 7064.

18. Achi OA, Koumi AR., Ouattara NI, Ossey YB, Atsé BC. Effects of Artemia Salina Substitution by Maggot Meal on Growth Performance and Body Composition of Africa Catfish Heterobranchus Longifilis (Valenciennes, 1840) Larvae. Journal of Animal Science Advances. 2016; 6 (10):1786-1793.

19. Ossey YB, Koumi AR, Koffi KM, Atsé BC, Kouamé LP. Growth performance, feed efficiency and body composition of larvae $H$. longifilis fed different beef brain meal dietary protein levels. International Journal of Science and Research. 2012a; 3 (7): 19641969.

20. Ossey YB, Koumi AR, Koffi KM, Atsé BC, Kouamé PL. Utilisation du soja de la cervelle bovine et de l'asticot comme source de protéines alimentaires chez les larves de Heterobranchus longifilis (Valenciennes, 1840) Journal of Animal \& Plant Sciences. 2012b; 15 (1): 2099-2108.

21. Slembrouck J, Legendre M. Aspects techniques de la reproduction contrôlée de Heterobranchus longifilis (Clariidae). Document Technique Abidjan, Côte d'Ivoire: Centre de Recherches Océanologiques ; 1988.

22. Koumi AR. Substitution de la farine de poisson par le tourteau de soja dans l'alimentation de Heterobranchus longifilis Valenciennes, 
1840, Sarotherodon melanotheron Rüppell, 1852 et Oreochromis niloticus (Linné, 1758) : Influence sur la qualité du milieu d'élevage, la croissance et la valeur nutritive des poissons. Thèse de Doctorat, Université Nangui Abrogoua, Côte d'Ivoire, 2010.

23. Legendre M. Seasonal changes in sexual maturity and fecundity and HCG-induced breeding of the catfish, Heterobranchus longifilis Val. (Claridae), reared in Ebrié Lagoon (Ivory Coast). Aquaculture. 1986; 55: 201-213.

24. Hecht T, Appelbaum A. Observations on intraspecific aggression and coeval sibling cannibalism by larval and juvenile Clarias gariepinus (Clariidae: Pisces) under controlled conditions. Journal of Zoologie. 1988; 214: 21- 44.

25. Haylor GS. Controlled hatchery production of Clarias gariepinus (Burchell). Growth and survival of fry at hight stocking density. Aquatic. Fishery Management. 1992; 23: 303-314.

26. AOAC. International Official Methods of Analysis. $18^{\text {th }}$ ed Gaithersburg, MD: AOAC international; 2005.

27. Luquet P, Moreau Y. Energy-protein management by some Warm Water fin fishes. Actes du colloque 9 Paris, France: AQUACOP, IFREMER; 1989.

28. Lee DJ, Sinnhuber RO. Lipid requirements. In: Halver JE, Editor. Fish Nutrition, New York: Academic Press; 1972, p. 145 - 180.

29. Keremah IR, Terimokumo T. Effects of dietary lipid sources on growth and survival of Mudfish Heterobranchus longifilis Fingerlings. Journal of Applied Biology \& Biotechnology. 2014; 2 (01): 009-012.

30. Sarkar SK. Fresh water fish culture. Vol. 1 Delhi-110035: Daya Publishing House; 2002.

31. Stickney RR, Hardy RW. Lipid requirements of some warm water species. Aquaculture. 1989; 79:145-156.
32. Ergun S, Yigit M, Tucker A. Harmantepe B Partial replacement of fish meal by defatted soybean meal in diets for black sea turbot (Psetta maeotica): Growth and nutrient utilization in winter. Israeli Journal of Aquaculture-Bamidgeh. 2008; 60: 175-182.

33. Ghanawi J, Roy L, Davis DA, Saoud IP. Effects of dietary lipid levels on growth performance of marbled spinefoot rabbitfish Siganus rivulatus. Aquaculture. 2011; 310: 395-400.

34. Cahu C. Domestication et fonction de nutrition chez les poissons Production Animale, INRA. 2004; 17: 205-210.

35. Barcellos LJG, Kreutz LC, Queuedo MR, Fioreze I, Cericato L, Sosso M, Fagundes AB, Conrad J, Baldissera RK, Bruschi A, and Ritter F. Nursery rearing of Rhamdia quelen (Quoy and Gaimard) in cages: Cage type, stocking density and stress response to confinement. Aquaculture. 2004; 232: 383-394.

\section{How to cite this article:}

Achi AO, Koumi RA, Ossey BY, Yté W, Ouattara IN, Atsé CB. Growth Performance and Survival of Clarias gariepinus Larvae Fed with Varying Inclusions of beef Brain Meal., J App Biol Biotech. 2017; 5 (05): 36-41. 